\title{
PENGARUH RELATIONSHIP MARKETING TERHADAP PENINGKATAN PENGUNJUNG PADA HOTEL HARPER PERINTIS MAKASSAR
}

\author{
Muh. Nur Rasyid \\ Universitas Muhammadiyah Makassar \\ Email: muhnurrasyid@unismuh.ac.id \\ Mahmud Nuhung \\ Universitas Muhammadiyah Makassar \\ Email: mahmudnuhung@unismuh.ac.id \\ Irwan Abdullah \\ Universitas Muhammadiyah Makassar \\ Email:irwanabdullah530@gmail.com \\ Ayu Indah Pratiwi Hamzah \\ Email:ayuindahpratiwihamzah@gmail.com \\ Universitas Muhammadiyah Makassar
}

\begin{abstract}
This study aims to analyze the influence of Relationship Marketing on increasing visitors to the Makassar Pioneer Harper Hotel. The type of research used in the study is simple linear regression. The population in this study were visitors to the Makassar Pioneer Harper Hotel in 2019, and the study sample totaled 99 respondents. The results of this study indicate that the variable relationship marketing can increase the number of visitors at the Makassar Pioneer Harper Hotel because relationship marketing is partially tested with the results of t test of 8,436>t table 1.98472 means that there is an influence between $x$ and $y$ and a significant value of 0,000<0,05 so that it can be said that there is an effect of variable relationship marketing on the variable increase in visitors.
\end{abstract}

Keywords: Relationship Marketing, Increased Visitors

\begin{abstract}
Abstrak
Penelitian ini bertujuan untuk menganalisis pengaruh Relationship Marketing terhadap peningkatan pengunjung pada Hotel Harper Perintis Makassar. Jenis Penelitian yang digunakan dalam penelitian ini adalah regresi linear sederhana. Populasi dalam penelitian ini adalah pengunjung Hotel Harper Perintis Makassar pada tahun 2019, dan sampel penelitian berjumlah 99 responden. Hasil penelitian ini menunjukkan bahwa variabel relationship marketing dapat meningkatkan jumlah mengunjung pada Hotel Harper Perintis Makassar karena relationship marketing di uji secara parsial dengan hasil uji t sebesar $8.436>t$ tabel 1.98472 artinya ada pengaruh antara $\mathrm{x}$ terhadap y dan nilai signifikan sebesar 0,000<0,05 sehingga dapat dikatakan bahwa pengaruh variabel relationship marketing terhadap variabel peningkatan pengunjung.
\end{abstract}

Kata Kunci: Relationship Marketing, Peningkatan Pengunjung 


\section{PENDAHULUAN}

Perkembangan persaingan bisnis perhotelan di Makassar adalah salah satu fenomena yang menarik untuk kita simak, terlebih dengan adanya globalisasi dalam bidang ekonomi yang semakin membuka peluang para pengusaha untuk turut menjaring konsumen.

Kota Makassar memiliki bisnis yang berkembang dan menjanjikan, salah satunya adalah dari segi bisnis perhotelan. Hal ini dapat terlihat dari peningkatan jumlah kamar untuk setiap hotel berbintang dan tingkat hunian.

Seiring berjalannya waktu, persaingan semakin ketat terjadi pada semua aspek. Saat ini aspek peningkatan pengunjung pada perusahaan perhotelan menjadi pusat perhatian sehingga perusahaan harus selalu mengikuti situasi untuk mendapatkan peluang pasar. Perusahaan perhotelan berupaya untuk mencari strategi yang tepat dalam menghadapi persaingan untuk meningkatkan jumlah pengunjung.

Perusahaan akan mampu bersaing dengan perusahaan lain jika memiliki strategi-strategi yang lebih unggul dari perusahaan pesaing. Pada umumnya perusahaan menginginkan seorang pelanggan yang bertahan selamanya, karena pelanggan yang setia merupakan suatu hal yang berharga bagi perusahaan.

Pada hakikatnya tujuan dari pemasaran adalah untuk mengetahui dan memahami sifat konsumen dengan baik sehingga produk yang ditawarkan dapat laku terjual seiring perkembangan hotel di Makassar, para manajemen hotel terpacu untuk semakin meningkatkan kualitas pelayanan hotel guna memperoleh konsumen sebanyakbanyaknya, beberapa strategi dilakukan para perusahaan hotel. Dahulu hotel hanya digunakan sebagai tempat menginap bagi para konsumen. Sekarang ini, hotel digunakan untuk acara pernikahan, rapat perusahaan, launching untuk sebuah produk baru suatu perusahaan dan tak jarang pula hotel digunakan untuk sarana berakhir pekan bagi kalangan masyarakat menengah keatas.

Sehubungan dengan bertambahnya penyedia jasa perhotelan yang membuat persaingan semakin ketat dan berkembangnya fungsi hotel yang sekarang bukan hanya sebagai tempat menginap bagi para konsumen berdampak pada tingkat kunjungan hotel mengalami pasan surut. Terkadang jumlah pengunjung meningkat dan tak jarang pula mengalami penurunan. Pihak hotel berusaha mengatasi hal tersebut dengan melakukan berbagai inovasi dan strategi pemasaran yang sesuai. Karena, pihak hotel menyadari tanpa inovasi dan strategi pemasaran maka berpotensi mengakibatkan kalah bersaing dengan perusahaan hotel lainnya.

Hotel Harper merupakan salah satu bisnis jasa penginapan yang ada di Makassar yang terletak di Jl. Perintis Kemerdekaan KM 15 No.14 A yang menawarkan tempat peristirahatan dengan menggunakan nuansa pedesaan dan menyediakan kamar tidur, makanan, dan minuman baik bagi anda yang sedang melaksanakan bisnis maupun rekreasi, guna memberikan suasana tentram, nyaman, sehat dan bersahabat yang dibutuhkan oleh konsumen/tamu.

Adanya inovasi yang terus menerus diupayakan pada bisnis jasa penginapan, bisa kita temui fasilitasfasilitas dan produk-produk yang berkualitas yang disajikan oleh para jasa penginapan. Upaya ini dilakukan guna 
memberikan suasana tenteram, nyaman, sehat dan bersahabat. Semua ini tidak lain hanya untuk menarik minat pelanggan atau konsumen agar mau menginap di jasa penginapan yang mereka tawarkan. Namun upaya tersebut tidak menjamin untuk meraih tujuan perusahaan yang tepat sasaran dalam memberi kepuasan secara lebih efesien dan efektif. Hal yang perlu dipikirkan oleh perusahaan adalah harus mampu untuk menghadapi para pesaing dan perusahaan sejenis yang semakin banyak bermunculan, perusahaan harus mampu bertahan dan berkembang dalam menghadapi persaingan usaha dalam jangka panjang.

Mencermati hal tersebut, strategi yang dapat dilakukan perusahaan perhotelan dalam mempertahankan eksitensinya adalah memfokuskan diri dalam membina hubungan dengan pelanggan dan dengan memberi imej dan layanan khusus kepada tamunya.

\section{Relationship}

Marketing diaplikasikan perusahaan perhotelan sebagai salah satu upaya untuk mempertahankan diri dalam dinamika bisnis. Ikatan hubungan secara luas dianggap sebagai alat untuk menjaga loyalitas sehingga menumbuhkan peningkatan pelanggan dan pengunjung.

Relationship Marketing merupakan penciptaan nilai dan pemeliharaan hubungan tahan lama antara perusahaan dengan pelanggan sehingga tercipta kepuasan bagi kedua belah pihak. Diketahui bahwa ikatan hubungan yang kuat dapat menciptakan kepuasan pelanggan, jika kepuasan yang dirasakan terus-menerus dalam jangka lama akan menumbuhkan peningkatan pengunjung dan pelanggan terhadap perusahaan perhotelan.
Menurut Kotler dan Keller (2013:20) relationship marketing adalah membangun hubungan jangka panjang yang saling memuaskan dengan pihakpihak kunci, untuk mendapatkan dan mempertahankan bisnis.

Berdasarkan penjelasan diatas, maka penulis tertarik untuk mengkaji dan mempelajari tentang pengaruh relationship marketing dalam peningkatan jumlah tamu menginap pada perusahaan yang dikelola oleh Hotel Harper Perintis di Kota Makassar. Oleh karena itu, penulis mengangkat persoalan ini dalam bentuk penelitian dengan judul "Pengaruh Relationship Marketing terhadap Peningkatan Pengunjung pada Hotel Harper Perintis Makassar".

\section{TINJAUAN PUSTAKA}

\subsection{Cara Menghitung Tingkat Hunian (Occupancy)}

Rumus menghitung tingkat hunian kamar atau Occupancyadalah Room Sold (kamar yang terjual) dibagi dengan Room Avalibility (Jumlah kamar yang tersedia) dikali 100\%. Hasil akhir dari perhitungannya adalah berupa index persentase yang diukur dari $0 \%$ hingga $100 \%$ dimana nilai persentase tertinggi adalah indicator terbaik bagi hotel dan service untuk staff makin tinggi juga.

\subsection{Kerangka Pikir}

Hotel Harper merupakan salah satu bisnis jasa penginapan yang ada di Makassar yang terletak di Jl. Perintis Kemerdekaan KM 15 No.14 A yang menawarkan tempat peristirahatan dengan menggunakan nuansa pedesaan dan menyediakan kamar tidur, makanan, dan minuman baik bagi anda yang sedang melaksanakan bisnis maupun rekreasi, guna memberikan suasana 
tenteram, nyaman, sehat dan bersahabat yang dibutuhkan oleh konsumen/tamu.

Menurut Sivesan (2013) ada 4 faktor yang mempengaruhi relationship marketing, diantaranya trust, commitment, communication dan conflict handling.

Trust (Kepercayaan) secara umum dipandang sebagai unsur mendasar bagi keberhasilan relationship marketing. Kepercayaan dapat tercipta ketika suatu pihak merasa nyaman melakukan pertukaran dengan pihak lain yang dengan penuh kejujuran dan dapat dipercaya. Kepercayaan merupakan variabel kunci dalam pengembangan keinginan yang kuat untuk mempertahankan sebuah hubungan jangka panjang. Untuk dapat mempertahankan pelanggan perusahaan tidak hanya mengandalkan pada kepuasan yang dirasakan oleh pelanggan, tetapi lebih dari itu bahwa kepercayaan merupakan perantara kunci dalam membangun keberhasilan pertukaran hubungan untuk meningkatkan pelanggan perusahaan.

\section{Commitment}

Perusahaan) merupakan inti dari relationship marketing. Komitmen perusahaan dapat diperoleh dengan cara perusahaan menjadikan pelanggan sebagai prioritas utama, berjangka panjang, dan berdasarkan pada hubungan yang saling menguntungkan. Komitmen perusahaan juga dapat diartikan sebagai janji atau ikrar perusahaan untuk memelihara hubungan yang telah terjalin dengan baik, karena hubungan tersebut memiliki arti penting. Hubungan jangka panjang haruslah saling memberi dan menerima. Artinya, baik penjual maupun pelanggan samasama mendapat keuntungan. Pelanggan yang menginginkan diskon besar, tentunya mengimbangi dengan pembayaran tunai.

\section{Communication (Komunikasi)}

merupakan alat perekat hubungan antara perusahaan dengan pelanggannya, sehingga komunikasi mempunyai peran vital dalam membina hubungan.Perusahaan orientasinya berusaha memenuhi keinginan dan kebutuhan pelanggan serta berusaha mendapatkan keuntungan yang berkelanjutan sangat membutuhkan peran komunikasi.

Komunikasi dalam relationship marketing berhubungan dengan nilai yang diperoleh pelanggan, memberikan informasi yang tepat dan dapat dipercaya serta informasi mengenai adanya perubahan jasa yang ditawarkan, dan komunikasi yang proaktif ketika terjadi masalah antara perusahaan dan pelanggan. Pelanggan selalu menginginkan terciptanya komunikasi yang efektif dengan perusahaan, komunikasi yang baik tentunya dapat meningkatkan kepercayaan pelanggan terhadap perusahaan.

Melalui komunikasi, pelanggan juga dapat mengemukakan ketidakpuasannya sehingga dapat dijadikan acuan bagi perusahaan untuk memperbaiki kinerjanya. Jika relationship marketing ingin berhasil, maka harus menyertakan semua pesan yang ada dalam komunikasi pemasaran, hal ini diperlukan dalam menciptakan, memelihara, dan memperluas hubungan dengan pelanggan. Komunikasi dapat dilakukan melalui komunikasi tertulis seperti surat menyurat, e-mail, web site, atau interaksi lainnya seperti komunikasi secara langsung dengan para karyawan perusahaan sebelum, selama, dan setelah melakukan transaksi. 


\section{Conflict Handling (Penanganan Konflilik) Kemampuan penanganan konflik mengacu pada kemampuan perusahaan untuk mencegah atau meminimalkan dampak hal-hal yang} potensial dapat menimbulkan konflik, dan kemampuan menyelesaikan konflik nyata yang sudah terjadi. Konflik dapat menjadi masalah yang serius di dalam perusahaan dan kemungkinan berpotensi menurunkan kinerja jika konflik tersebut dibiarkan berlarut-larut tanpa penyelesaian.

Penanganan konflik merupakan tindakan khusus pada saat melakukan interaksi dengan pelanggan (Ball at al; 2014) Kemampuan pihak perusahaan dalam menangani konflik dengan baik akan memberikan kepuasan pada pelanggan dan menyebabkan pelanggan menjadi loyal.

Keempat dimensi relationship marketing tersebut merupakan satu kesatuan yang saling berkaitan, yang bertujuan untuk mewujudkan hubungan yang baik antara perusahaan dengan pelanggannya sehingga akan tercipta suatu hubungan yang saling menguntungkan dalam jangka panjang antara pelanggan dan perusahaan. Membangun kepercayaan, komitmen perusahaan, komunikasi, dan kemampuan penanganan konflik merupakan kunci pokok dalam penerapan relationship marketing.

Berdasarkan uraian di atas, maka selanjutnya disusunlah kerangka pemikiran yang menuju kepada jawaban sementara dari penelitian yang telah dirumuskan sebagai berikut:

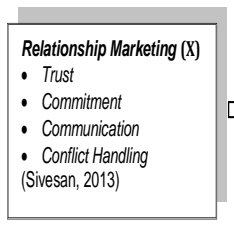

$$
\begin{aligned}
& \text { Peningkatan Pengunjung (Y) } \\
& \text { - Secara pangsa pasar mengalami pertumbuhan tiap tahun } \\
& \text { - Hotel menjadi trending topik } \\
& \text { - Dianggap selalu melakukan inovasi dan kreatif } \\
& \text { - Dapat menjual kamar dan produk lainnya dengan harga } \\
& \text { premium } \\
& \text { (Sumarsono, 2014) }
\end{aligned}
$$

\section{METODE PENELITIAN}

\subsection{Teknik Analisis Data}

a. Uji Validitas dan Reliabilitas

Validitas digunakan untuk mengetahui kelayakan butir-butir dalam suatu pertanyaan dalam mendefinisikan suatu variabel.Daftar pertanyaan ini pada umumnya mendukung suatu kelompok variabel tertentu. Dalam penelitian ini, dikatakan valid jika mampu mengukur apa yang hendak diukur dari variabel yang diteliti. Pengukuran validitas dilakukan dengan menggunakan rumus product moment person dan taraf signifikan 0,05 atau $5 \%$.

Uji validilitas sebaiknya dilakukan pada setiap butir pertanyaan di uji validitas yang dilakukan dengan bantuan SPSS Versi 25. Hasil $r$ hitung kita bandingkan dengan $\mathrm{r}$ table dimana $\mathrm{df}=$ n-2 dengan signifikan 0,05 atau 5\%. Jika $r$ table $<$ r hitung maka valid.

b. Uji Reabilitas

Uji reabilitas (keandalan) merupakan ukuran suatu kestabilan dan konsistensi responden dalam menjawab hal yang berkaitan dengan kontrukkontruk pertanyaan yang merupakan dimensi suatu variabel dan disusun dalam suatu bentuk kuesioner. Jika nilai alpha>0,6 maka realibel atau konsisten.

1. Uji Asumsi Klasik (Uji Normalitas Kolmogorov Smirnov residual)

Uji normalitas data ini sebaiknya dilakukan sebelum data diolah berdasarkan model-model penelitian. Uji normalitas ini bertujuan mengetahui distribusi data apakah normal atau tidak dalam variabel yang akan digunakan dalam penelitian. Data yang baik dan layak digunakan dalam penelitian adalah data yang memiliki distribusi normal. Normalitas data dapat dilihat dengan menggunakan uji Normal Kolmogorov- 
Smirnov jika nilai signifikan> 0,05 maka data berdistribusi normal dan sebaliknya jika nilai signifikan $<0,05$ maka data berdistribusi tidak normal.

2. Analisi Regresi Linear Sederhana Analisi yang digunakan dalam penelitian ini adalah Analisis Regresi Linear Sederhana yang dimana analisis ini didasarkan pada hubungan fungsional ataupun kausal satu variabel independen dengan satu variabel dependen. Persamaan umum regresi linier sederhana adalah:

$Y^{\prime}=a+b X$

Dimana:

$\mathrm{Y}=$ Subjek dalam variabel dependen yang diprediksikan

$\mathrm{a}=$ Konstanta

$\mathrm{b}=$ Angka arah atau koefisien regresi, yang menunjukkan angka peningkatan ataupun penurunan variabel dependen yang didasarkan pada variabel independen. Bila b (+) maka naik, bila (-) maka terjadi penurunan.

$\mathrm{X}=$ Subjek pada variabel independen yang mempunyai nilai tertentu.

Untuk mengetahui besar pengaruh variabel $\mathrm{x}$ terhadap variabel $\mathrm{y}$ dapat dilihat dari output Coefficients pada tabel Unstandardized Coefficients hasil perhitungan SPSS Versi 20.

\section{Uji Hipotesis}

Pengujian hipotesis dapat dengan menggunakan uji statistik sebagai berikut:

a) Uji Parsial ( $t$ )

Uji ini digunakan untuk mengetahui apakah variabel independen secara parsial mempunyai pengaruh yang signifikan terhadap variabel dependen. Adapun langkah-langkah pengujian hipotesis sebagai berikut:

1) Hipotesis

Ho: Tidak ada hubungan secara signifikan antara relationship marketing terhadap peningkatan pengunjung.

Ha: Ada hubungan secara signifikan antara relationship marketing terhadap peningkatan pengunjung.

2) Tingkat signifikansi Tingkat signifikansi yang digunakan adalah $0,05(\alpha=5 \%)$

- Jika signifikansi $t_{\text {hitung }}>0,05$, berarti Ho diterima atau Ha ditolak.

- Jika signifikansi $t_{\text {hitung }}<0,05$, berarti Ho ditolak atau Ha terima.

b) Uji Determinasi

Uji determinasi digunakan untuk mengetahui persentase sumbangan pengaruh serentak variabel-variabel bebas terhadap variabel terikat untuk itu digunakan angka-angka pada tabel model summary.

\section{HASIL DAN PEMBAHASAN}

\subsection{Hasil Penelitian}

a. Analisis Deskriptif Variabel Relationship Marketing(x)

\section{Trust (Kepercayaan)}

Berdasarkan data yang diperoleh dari responden dengan pernyataan "saya percaya bahwa Hotel Harper Perintis Makassar memiliki nama baik dikalangan masyarakat" dapat disimpulkan dalam tabel berikut ini: 
Tabel 4.5 Jawaban Responden terhadap Pernyataan 1

\begin{tabular}{llllll} 
No. & \multicolumn{1}{c}{ Jawaban } & Skala & Frekuensi & Presentase (\%) \\
\hline $\mathbf{1 .}$ & Sangat Setuju & 5 & 13 & 13,13 & \\
\hline 2. & Setuju & 4 & 46 & 46,47 & \\
\hline 3. & Kurang Setuju & 3 & 28 & 28,28 & \\
\hline 4. & Tidak Setuju & 2 & 11 & 11,11 & \\
\hline $\mathbf{5 .}$ & Sangat Tidak Setuju & 1 & 1 & 1,01 & $\mathbf{1 0 0}$
\end{tabular}

Sumber: Data Primer Olahan, 2019

Pada tabel di atas, tanggapan responden pada Hotel Harper Perintis Makassar menyatakan bahwa 13 responden "sangat setuju", atau 13,13\%, 46 responden "setuju" atau 46,47\%, 28responden "kurang setuju" atau $28,28 \%, 11$ responden "tidak setuju" atau $11,11 \%$, dan 1 responden "sangat tidak setuju" atau 1,01\%. Sehingga total responden yang berpasrtisipasi dalam pengisian kuesioner ini sebanyak 99 responden dengan total persentase $100 \%$.

Berdasarkan data yang diperoleh dari responden dengan pernyataan "saya percaya bahwa informasi yang disajikan Hotel Harper Perintis Makassar mengenai hunian hotel dapat menarik pengunjung." dapat disimpulkan dalam tabel berikut ini:

Tabel 4.6 Jawaban Responden terhadap Pernyataan 2

\begin{tabular}{|c|c|c|c|c|}
\hline No & Jawaban & Skala & Frekuensi & Presentase (\%) \\
\hline 1. & Sangat Setuju & 5 & 9 & 9,09 \\
\hline 2. & Setuju & 4 & 45 & 45,46 \\
\hline 3. & Kurang Setuju & 3 & 34 & 34,34 \\
\hline 4. & Tidak Setuju & 2 & 10 & 10,10 \\
\hline 5. & Sangat Tidak Setuju & 1 & 1 & 1,01 \\
\hline \multicolumn{3}{|c|}{ Total } & 99 & 100 \\
\hline
\end{tabular}

Sumber: Data Primer Olahan, 2019

Pada tabel di atas, tanggapan responden pada Hotel Harper Perintis Makassar menyatakan bahwa 9 responden "sangat setuju", atau 9,09\%, 45 responden "setuju" atau 45,46\%, 34responden "kurang setuju" atau 34,34\%, 10 responden "tidak setuju" atau $10,10 \%$, dan 1 responden "sangat tidak setuju" atau 1,01\%. Sehingga total responden yang berpasrtisipasi dalam pengisian kuesioner ini sebanyak 99 responden dengan total persentase $100 \%$.

\section{1) Commitment (Komitmen)}

Berdasarkan data yang diperoleh dari responden dengan pernyataan "menurut saya, komitmen Hotel Harper Perintis Makassar dalam memberikan pelayanan sesuai dengan yang dijanjikan." dapat disimpulkan dalam tabel berikut ini: 
Tabel 4.7 Jawaban Responden terhadap Pernyataan 1

\begin{tabular}{|c|c|c|c|c|c|}
\hline \multirow[t]{2}{*}{ No. } & \multirow[t]{2}{*}{ Jawaban } & \multirow[b]{2}{*}{ kala } & \multicolumn{2}{|c|}{$\mathrm{Fr}$} & \multirow{2}{*}{$\begin{array}{l}\text { Presentase } \\
\text { (\%) }\end{array}$} \\
\hline & & & ekuensi & & \\
\hline & Sangat Setuju & 5 & 17 & 17,18 & \\
\hline & Setuju & 4 & 50 & 50,50 & \\
\hline & Kurang Setuju & 3 & 22 & 22,22 & \\
\hline & Tidak Setuju & 2 & 9 & 9,09 & \\
\hline & Sangat Tidak Setuju & & 1 & 1,01 & \\
\hline & Total & & 99 & 100 & \\
\hline
\end{tabular}

Sumber: Data Primer Olahan, 2019

Pada tabel di atas, tanggapan responden pada Hotel Harper Perintis Makassar menyatakan bahwa 17 responden "sangat setuju", atau $17,17 \%$, 50 responden "setuju" atau 50,50\%, 22 responden "kurang setuju" atau 22,22\%, 9responden "tidak setuju" atau 9,09\%, dan 1 responden "sangat tidak setuju" atau $1,01 \%$. Sehingga total responden yang berpasrtisipasi dalam pengisian kuesioner ini sebanyak 99 responden dengan total persentase $100 \%$.

Berdasarkan data yang diperoleh dari responden dengan pernyataan "menurut saya, Hotel Harper Perintis Makassar dapat memberikan pelayanan dalam waktu yang tepat." dapat disimpulkan dalam tabel berikut ini:

Tabel 4.8 Jawaban Responden terhadap Pernyataan 2

\begin{tabular}{|l|l|c|c|c|}
\hline No. & \multicolumn{1}{|c|}{ Jawaban } & Skala & Frekuensi & $\begin{array}{c}\text { Presentase } \\
\text { (\%) }\end{array}$ \\
\hline 1. & Sangat Setuju & 5 & 15 & 15,15 \\
\hline 2. & Setuju & 4 & 47 & 47,47 \\
\hline 3. & Kurang Setuju & 3 & 26 & 26,27 \\
\hline $\mathbf{4 .}$ & Tidak Setuju & 2 & 10 & 10,10 \\
\hline $\mathbf{5 .}$ & Sangat Tidak Setuju & 1 & 1 & 1,01 \\
\hline & Total & & 99 & 100 \\
\hline
\end{tabular}

Sumber: Data Primer Olahan, 2019

Pada tabel di atas, tanggapan responden pada Hotel Harper Perintis Makassar menyatakan bahwa 15 responden "sangat setuju", atau $15,15 \%$, 47 responden "setuju" atau 47,47\%, 26responden "kurang setuju" atau $26,27 \%, 10$ responden "tidak setuju" atau 10,10\%, dan 1 responden "sangat tidak setuju" atau 1,01\%. Sehingga total responden yang berpasrtisipasi dalam pengisian kuesioner ini sebanyak 99 responden dengan total persentase $100 \%$.

\section{2) Communication (Komunikasi)}

Berdasarkan data yang diperoleh dari responden dengan pernyataan "menurut saya, kemampuan berkomunikasi Hotel Harper Perintis Makassar dalam keterbukaan memberikan informasi seputar hunian kamar atau produk sangat baik." dapat disimpulkan dalam tabel berikut ini: 
Tabel 4.9 Jawaban Responden terhadap Pernyataan 1

\begin{tabular}{|c|c|c|c|c|}
\hline No. & Jawaban & Skala & Frekuensi & Presentase (\%) \\
\hline 1. & Sangat Setuju & 5 & 14 & 14,14 \\
\hline 2. & Setuju & 4 & 38 & 38,38 \\
\hline 3. & Kurang Setuju & 3 & 35 & 35,36 \\
\hline 4. & Tidak Setuju & 2 & 12 & 12,12 \\
\hline 5. & Sangat Tidak Setuju & 1 & 0 & 0 \\
\hline \multicolumn{3}{|c|}{ Total } & 99 & 100 \\
\hline
\end{tabular}

Sumber: Data Primer Olahan, 2019

Pada tabel di atas, tanggapan responden pada Hotel Harper Perintis Makassar menyatakan bahwa 14 responden "sangat setuju", atau $14,14 \%$, 38 responden "setuju" atau 38,38\%, 35responden "kurang setuju" atau $35,36 \%, 12$ responden "tidak setuju" atau $12,12 \%$, dan 0 responden "sangat tidak setuju" atau $0 \%$. Sehingga total responden yang berpasrtisipasi dalam pengisian kuesioner ini sebanyak 99 responden dengan total persentase $100 \%$.

Berdasarkan data yang diperoleh dari responden dengan pernyataan "menurut saya, kemampuan berkomunikasi Hotel Harper Perintis Makassar sangat cepat dalam merespon berbagai pertanyaan dari masyarakat." dapat disimpulkan dalam tabel berikut ini:

Tabel 4.10 Jawaban Responden terhadap Pernyataan 2

\begin{tabular}{|l|l|l|l|l|}
\hline No & Jawaban & Skala & Frekuensi & Presentase (\%) \\
\hline 1. & Sangat Setuju & 5 & 13 & 13,13 \\
\hline 2. & Setuju & 4 & 44 & 44,45 \\
\hline 3. & Kurang Setuju & 3 & 33 & 33,33 \\
\hline 4. & Tidak Setuju & 2 & 9 & 9,09 \\
\hline 5. & Sangat Tidak Setuju & 1 & 0 & 0 \\
\hline \multicolumn{2}{r}{ Total } & 99 & 100 \\
\hline
\end{tabular}

Sumber: Data Primer Olahan, 2019

Pada tabel di atas, tanggapan responden pada Hotel Harper Perintis Makassar menyatakan bahwa 13 responden "sangat setuju", atau $13,13 \%$, 44 responden "setuju" atau 44,45\%, 33 responden "kurang setuju" atau 33,33\%, 9 responden "tidak setuju" atau 9,09\%, dan 0 responden "sangat tidak setuju" atau $0 \%$. Sehingga total responden yang berpasrtisipasi dalam pengisian kuesioner ini sebanyak 99 responden dengan total persentase $100 \%$.

\section{3) Conflict Handling (Penanganan Konflik)}

Berdasarkan data yang diperoleh dari responden dengan pernyataan "menurut saya, Hotel Harper Perintis Makassar sangat cekatan dalam menangani masalah apabila terjadi kesalahan" dapat disimpulkan dalam tabel berikut ini: 
Tabel 4.11 Jawaban Responden terhadap Pernyataan 1

\begin{tabular}{|l|c|c|c|c|}
\hline No. & Jawaban & Skala & Frekuensi & Presentase (\%) \\
\hline 1. & Sangat Setuju & 10 & 10,10 \\
\hline 2. & Setuju & 53 & 53,53 \\
\hline 3. & Kurang Setuju & 27 & 27,28 \\
\hline 4. & Tidak Setuju & 8 & 8,08 \\
\hline 5. & Sangat Tidak Setuju & 1 & 1,01 \\
\hline & Total & 99 & 100 \\
\hline
\end{tabular}

Sumber: Data Primer Olahan, 2019

Pada tabel di atas, tanggapan responden pada Hotel Harper Perintis Makassar menyatakan bahwa 10 responden "sangat setuju", atau $10,10 \%$, 53 responden "setuju" atau 53,53\%, 27 responden "kurang setuju" atau $27,28 \%$, 8responden "tidak setuju" atau 8,08\%, dan 1 responden "sangat tidak setuju" atau $1,01 \%$. Sehingga total responden yang berpasrtisipasi dalam pengisian kuesioner ini sebanyak 99 responden dengan total persentase $100 \%$.

Berdasarkan data yang diperoleh dari responden dengan pernyataan "menurut saya,Hotel Harper Perintis Makassar sangat responsif dalam menangani keluhan masalah." dapat disimpulkan dalam tabel berikut ini:

Tabel 4.12 Jawaban Responden terhadap Pernyataan 2

\begin{tabular}{|c|l|c|c|c|}
\hline No. & \multicolumn{1}{|c|}{ Jawaban } & Skala & Frekuensi & Presentase (\%) \\
\hline $\mathbf{1 .}$ & Sangat Setuju & 5 & 11 & 11,11 \\
\hline 2. & Setuju & 4 & 53 & 53,54 \\
\hline 3. & Kurang Setuju & 3 & 23 & 23,23 \\
\hline $\mathbf{4 .}$ & Tidak Setuju & 2 & 11 & 11,11 \\
\hline $\mathbf{5 .}$ & Sangat Tidak Setuju & 1 & 1 & 1,01 \\
\hline & & & 99 & 100 \\
\hline
\end{tabular}

Sumber: Data Primer Olahan, 2019

Pada tabel di atas, tanggapan responden pada Hotel Harper Perintis Makassar menyatakan bahwa 11 responden "sangat setuju", atau $11,11 \%$, 53 responden "setuju" atau 53,54\%, 23responden "kurang setuju" atau $23,23 \%, 11$ responden "tidak setuju" atau $11,11 \%$, dan 1 responden "sangat tidak setuju" atau 1,01\%. Sehingga total responden yang berpasrtisipasi dalam pengisian kuesioner ini sebanyak 99 responden dengan total persentase $100 \%$.

\section{b. Analisis Deskriptif Variabel Peningkatan Pengunjung (y)}

Berdasarkan data yang diperoleh dari responden dengan pernyataan "alasan anda memilih Hotel Harper Perintis Makassar karena kebiasaan" dapat disimpulkan dalam tabel berikut ini: 
Tabel 4.13 Jawaban Responden terhadap Pernyataan 1

\begin{tabular}{|l|l|l|l|l|}
\hline No. & Jawaban & Skala & Frekuensi & Presentase (\%) \\
\hline 1. & Sangat Setuju & 5 & 13 & 13,13 \\
\hline 2. & Setuju & 4 & 55 & 55,56 \\
\hline 3. & Kurang Setuju & 3 & 21 & 21,21 \\
\hline 4. & Tidak Setuju & 2 & 9 & 9,09 \\
\hline 5. & Sangat Tidak Setuju & 1 & 1 & 1,01 \\
\hline \multicolumn{1}{r}{ Total } & & 99 & 100 \\
\hline
\end{tabular}

Sumber: Data Primer Olahan, 2019

Pada tabel di atas, tanggapan responden pada Hotel Harper Perintis Makassar menyatakan bahwa 13 responden "sangat setuju", atau 13,13\%, 55 responden "setuju" atau 55,56\%, 21responden "kurang setuju" atau $21,21 \%$, 9responden "tidak setuju" atau 9,09\%, dan 1 responden "sangat tidak setuju" atau 1,01\%. Sehingga total responden yang berpasrtisipasi dalam pengisian kuesioner ini sebanyak 99 responden dengan total persentase $100 \%$.

Berdasarkan data yang diperoleh dari responden dengan pernyataan "apakah anda nyaman dengan pelayanan yang diberikan Hotel Harper Perintis Makassar" dapat disimpulkan dalam tabel berikut ini:

Tabel 4.14 Jawaban Responden terhadap Pernyataan 2

\begin{tabular}{|l|l|l|l|l|}
\hline No. & Jawaban & Skala & Frekuensi & Presentase (\%) \\
\hline $\mathbf{1 .}$ & Sangat Setuju & 5 & 24 & 24,24 \\
\hline 2. & Setuju & 4 & 57 & 57,58 \\
\hline 3. & Kurang Setuju & 3 & 13 & 13,13 \\
\hline 4. & Tidak Setuju & 2 & 5 & 5,05 \\
\hline 5. & Sangat Tidak Setuju & 1 & 0 & \\
\hline \multicolumn{2}{|c|}{ Total } & 99 & 100 \\
\hline
\end{tabular}

Sumber: Data Primer Olahan, 2019

Pada tabel di atas, tanggapan responden pada Hotel Harper Perintis Makassar menyatakan bahwa 24 responden "sangat setuju", atau $24,24 \%$, 57 responden "setuju" atau 57,58\%, 13responden "kurang setuju" atau 13,13\%, 5 responden "tidak setuju" atau $5,05 \%$, dan 0 responden "sangat tidak setuju" atau $0 \%$. Sehingga total responden yang berpasrtisipasi dalam pengisian kuesioner ini sebanyak 99 responden dengan total persentase $100 \%$.

Berdasarkan data yang diperoleh dari responden dengan pernyataan "apakah karyawan Hotel Harper Perintis Makassar ramah dan sopan kepada pengunjung" dapat disimpulkan dalam tabel berikut ini: 
Tabel 4.15 Jawaban Responden terhadap Pernyataan 3

\begin{tabular}{|l|l|l|l|l|}
\hline No. & Jawaban & Skala & Frekuensi & Presentase (\%) \\
\hline 1. & Sangat Setuju & 5 & 15 & 15,16 \\
\hline 2. & Setuju & 4 & 60 & 60,60 \\
\hline 3. & Kurang Setuju & 3 & 16 & 16,16 \\
\hline 4. & Tidak Setuju & 2 & 7 & 7,07 \\
\hline $\mathbf{5 .}$ & Sangat Tidak Setuju & 1 & 1 & 1,01 \\
\hline & \multicolumn{1}{c}{ Total } & & 99 & 100 \\
\hline
\end{tabular}

Sumber: Data Primer Olahan, 2019

Pada tabel di atas, tanggapan responden pada Hotel Harper Perintis Makassar menyatakan bahwa 15 responden "sangat setuju", atau $15,16 \%$, 60 responden "setuju" atau 60,60\%, 16responden "kurang setuju" atau $16,16 \%$, 7responden "tidak setuju" atau $7,07 \%$, dan 1 responden "sangat tidak setuju" atau 1,01\%. Sehingga total responden yang berpasrtisipasi dalam Tabel 4.16 Jawaban Responden terhadap Pernyataan 4

\begin{tabular}{|c|c|c|c|c|}
\hline No. & Jawaban & Skala & Frekuensi & Presentase (\%) \\
\hline 1. & Sangat Setuju & 5 & 29 & 29,29 \\
\hline 2. & Setuju & 4 & 58 & 58,59 \\
\hline 3. & Kurang Setuju & 3 & 9 & 9,09 \\
\hline 4. & Tidak Setuju & 2 & 3 & 3,03 \\
\hline 5. & Sangat Tidak Setuju & 1 & 0 & 0 \\
\hline \multicolumn{3}{|c|}{ Total } & 99 & 100 \\
\hline
\end{tabular}

Sumber: Data Primer Olahan, 2019

Pada tabel di atas, tanggapan responden pada Hotel Harper Perintis Makassar menyatakan bahwa 29 responden "sangat setuju", atau 29,29\%, 58 responden "setuju" atau 58,59\%, 9 responden "kurang setuju" atau 9,09\%, 3responden "tidak setuju" atau 3,03\%, dan 0 responden "sangat tidak setuju" atau $0 \%$. Sehingga total responden yang berpasrtisipasi dalam pengisian kuesioner ini sebanyak 99 responden dengan total persentase $100 \%$. pengisian kuesioner ini sebanyak 99 responden dengan total persentase $100 \%$.

Berdasarkan data yang diperoleh dari responden dengan pernyataan "anda benar-benar menyukai fasilitas yang diberikan Hotel Harper Perintis Makassar." dapat disimpulkan dalam tabel berikut ini: 
Tabel 4.17 Jawaban Responden terhadap Pernyataan 5

\begin{tabular}{|l|l|c|c|c|}
\hline No. & Jawaban & Skala & Frekuensi & Presentase(\%) \\
\hline 1. & Sangat Setuju & 5 & 11 & 11,11 \\
\hline 2. & Setuju & 4 & 58 & 58,58 \\
\hline 3. & Kurang Setuju & 3 & 25 & 25,26 \\
\hline 4. & Tidak Setuju & 2 & 5 & 5,05 \\
\hline $\mathbf{5 .}$ & Sangat Tidak Setuju & 1 & 0 & 0 \\
\hline \multicolumn{2}{|c|}{ Total } & & 99 & 100 \\
\hline
\end{tabular}

Sumber: Data Primer Olahan, 2019

Pada tabel di atas, tanggapan responden pada Hotel Harper Perintis Makassar menyatakan bahwa 11 responden "sangat setuju", atau $11,11 \%$, 58 responden "setuju" atau 58,58\%, 25responden "kurang setuju" atau 25,26\%, 5 responden "tidak setuju" atau $5,05 \%$, dan 0 responden "sangat tidak setuju" atau $0 \%$. Sehingga total responden yang berpasrtisipasi dalam

Tabel 4.18 Jawaban Responden terhadap Pernyataan 6

\begin{tabular}{|c|c|c|c|c|}
\hline No. & Jawaban & Skala & Frekuensi & Presentase(\%) \\
\hline 1. & Sangat Setuju & 5 & 27 & 27,27 \\
\hline 2. & Setuju & 4 & 55 & 55,56 \\
\hline 3. & Kurang Setuju & 3 & 11 & 11,11 \\
\hline 4. & Tidak Setuju & 2 & 6 & 6,06 \\
\hline 5. & Sangat Tidak Setuju & 1 & 0 & 0 \\
\hline \multicolumn{3}{|c|}{ Total } & 99 & 100 \\
\hline \multicolumn{2}{|c|}{ Sumber: } & \multicolumn{2}{|c|}{ Primer } & ahan, \\
\hline \multicolumn{3}{|c|}{$\begin{array}{l}\text { Pada tabel di atas, tanggapan } \\
\text { onden pada Hotel Harper Perintis }\end{array}$} & \multicolumn{2}{|c|}{$\begin{array}{l}\text { Makassar brulang-ulang atau lebih dari } \\
\text { satu kali" dapat disimpulkan dalam tabel } \\
\text { berikut ini: }\end{array}$} \\
\hline
\end{tabular}

pengisian kuesioner ini sebanyak 99 responden dengan total persentase $100 \%$.

Berdasarkan data yang diperoleh dari responden dengan pernyataan "apakah kualitas jasa sesuai dengan yang ditawarkan Hotel Harper Perintis Makassar." dapat disimpulkan dalam tabel berikut ini: responden "sangat setuju", atau 27,27\%, 55 responden "setuju" atau 55,56\%, 11responden "kurang setuju" atau 11,11\%, 6 responden "tidak setuju" atau $6,06 \%$, dan 0 responden "sangat tidak setuju" atau $0 \%$. Sehingga total responden yang berpasrtisipasi dalam pengisian kuesioner ini sebanyak 99 responden dengan total persentase $100 \%$.

Berdasarkan data yang diperoleh dari responden dengan pernyataan "anda menginap di Hotel Harper Perintis 
Tabel 4.19 Jawaban Responden terhadap Pernyataan 7

\begin{tabular}{|l|l|r|r|r|}
\hline No. & Jawaban & Skala & Frekuensi & Presentase(\%) \\
\hline 1. & Sangat Setuju & 5 & 12 & 12,12 \\
\hline 2. & Setuju & 4 & 50 & 50,51 \\
\hline 3. & Kurang Setuju & 3 & 11 & 11,11 \\
\hline 4. & Tidak Setuju & 2 & 6 & 6,06 \\
\hline 5. & Sangat Tidak Setuju & 1 & 0 & 0 \\
\hline \multicolumn{2}{|r|}{ Total } & & 99 & 100 \\
\hline
\end{tabular}

Sumber: Data Primer Olahan, 2019

Pada tabel di atas, tanggapan responden pada Hotel Harper Perintis Makassar menyatakan bahwa 12 responden "sangat setuju", atau $12,12 \%$, 50 responden "setuju" atau 50,51\%, 11responden "kurang setuju" atau $11,11 \%$, 6responden "tidak setuju" atau 6,06\%, dan 0 responden "sangat tidak setuju" atau $0 \%$. Sehingga total responden yang berpasrtisipasi dalam pengisian kuesioner ini sebanyak 99 responden dengan total persentase $100 \%$.

Berdasarkan data yang diperoleh dari responden dengan pernyataan "Anda merasa puas berkunjung ke Hotel Harper Perintis Makassar" dapat disimpulkan dalam tabel berikut ini:

Tabel 4.20 Jawaban Responden terhadap Pernyataan 8

\begin{tabular}{|l|l|c|c|c|}
\hline No. & Jawaban & Skala & Frekuensi & Presentase(\%) \\
\hline $\mathbf{1 .}$ & Sangat Setuju & 5 & 31 & 31,31 \\
\hline $\mathbf{2 .}$ & Setuju & 4 & 56 & 56,57 \\
\hline $\mathbf{3 .}$ & Kurang Setuju & 3 & 8 & 8,08 \\
\hline $\mathbf{4 .}$ & Tidak Setuju & 2 & 4 & 4,04 \\
\hline $\mathbf{5 .}$ & Sangat Tidak Setuju & 1 & 0 & 0 \\
\hline & Total & & 99 & 100 \\
\hline
\end{tabular}

Sumber: Data Primer Olahan, 2019

Pada tabel di atas, tanggapan responden pada Hotel Harper Perintis Makassar menyatakan bahwa 31 responden "sangat setuju", atau 31,31\%, 56 responden "setuju" atau 56,57\%, 8responden "kurang setuju" atau 8,08\%, 4responden "tidak setuju" atau 4,04\%, dan 0 responden "sangat tidak setuju" atau $0 \%$. Sehingga total responden yang berpasrtisipasi dalam pengisian kuesioner ini sebanyak 99 responden dengan total persentase $100 \%$.

\section{c. Uji Validitas dan Reabilitas}

1. Uji Validitas

Uji validitas digunakan untuk mengukur sah atau tidaknya suatu kuesioner. Uji validitas dihitung dengan membandingkan nilai $r$ hitung (correlated item-total correlation) dengan nilai $r$ tabel, jika $r$ hitung $>$ dari $r$ tabel (pada taraf signifikansi 5\%) maka pernyataan tersebut dinyatakan valid. Hasil penguian diperoleh sebagai berikut: 
Tabel 4.21 Uji Validitas Variabel

\begin{tabular}{|c|c|c|c|c|}
\hline \multirow{2}{*}{\multicolumn{2}{|c|}{$\begin{array}{c}\text { Variabel } \\
\text { Relationship Marketing }\end{array}$}} & \multirow[b]{2}{*}{ R_hitung } & \multirow[b]{2}{*}{ R -tabel(5\%) } & \multirow[b]{2}{*}{ KETERANGAN } \\
\hline & & & & \\
\hline \multirow{8}{*}{$\mathbf{X}$} & Pertanyaan 1 & 0,935 & 0,197 & Valid \\
\hline & Pertanyaan 2 & 0,715 & 0,197 & Valid \\
\hline & Pertanyaan 3 & 0,855 & 0,197 & Valid \\
\hline & Pertanyaan 4 & 0,926 & 0,197 & Valid \\
\hline & Pertanyaan 5 & 0,926 & 0,197 & Valid \\
\hline & Pertanyaan 6 & 0,876 & 0,197 & Valid \\
\hline & Pertanyaan 7 & 0,699 & 0,197 & Valid \\
\hline & Pertanyaan 8 & 0,830 & 0,197 & Valid \\
\hline \multicolumn{5}{|c|}{ Peningkatan Pengunjung } \\
\hline \multirow{8}{*}{$\mathbf{Y}$} & Pertanyaan 1 & 0,689 & 0,197 & Valid \\
\hline & Pertanyaan 2 & 0,745 & 0,197 & Valid \\
\hline & Pertanyaan 3 & 0,480 & 0,197 & Valid \\
\hline & Pertanyaan 4 & 0,437 & 0,197 & Valid \\
\hline & Pertanyaan 5 & 0,794 & 0,197 & Valid \\
\hline & Pertanyaan 6 & 0,562 & 0,197 & Valid \\
\hline & Pertanyaan 7 & 0,771 & 0,197 & Valid \\
\hline & Pertanyaan 8 & 0,408 & 0,197 & Valid \\
\hline
\end{tabular}

Berdasarkan tabel hasil uji validitas tersebut, dapat diketahui bahwa semua nilai $\mathrm{r}_{\text {hitung }}$ lebih besar dari $\mathrm{r}_{\text {tabel }} \mathrm{n}$ $2=97(0,197)$ pada taraf signifikansi 5\%. Artinya tiap item pernyataan/indicator variable kualitas pelayanan dan kepuasan pelanggan berkorelasi dengan skor totalnya serta data yang dikumpulkan dinyatakan valid dan siap untuk dianalisis.

\section{Uji Reliabilitas}

Uji reliabilitas digunakan untuk mengetahui konsistensi alat ukur, Tabel 4.22Uji Reliabilitas Variabel apakah alat ukur yang digunakan dapat diandalkan dan tetap konsisten jika pengukuran tersebut diulang. Bila suatu alat pengukur dipakai dua kali untuk mengukur gejala yang sama dan hasil pengukuran yang diperoleh relatif konsisten, maka alat pengukur tersebut reliabel. Instrumen yang reliabel adalah instrument yang bila digunakan beberapa kali untuk mengukur objek yang sama akan menghasilkan data yang sama. Adapun secara ringkas hasil uji reliabilitas ditunjukkan tabel berikut:

\begin{tabular}{|l|c|c|c|c|}
\hline Variabel & $\begin{array}{l}\text { Reliability } \\
\text { Coeficients }\end{array}$ & $\begin{array}{l}\text { Alfa Cronbach } \\
\text { variabel }\end{array}$ & $\begin{array}{l}\text { Alfa } \\
\text { Cronbach }\end{array}$ & Keterangan \\
\hline $\begin{array}{l}\text { Relationship } \\
\text { Marketing (x) }\end{array}$ & 8 item & 0,959 & 0,6 & Reliabel \\
\hline $\begin{array}{l}\text { Peningkatan } \\
\text { Pengunjung (y) }\end{array}$ & 8 item & 0,861 & 0,6 & Reliabel \\
$\begin{array}{l}\text { Dalam penelitian ini, Uji reliabilitas } \\
\text { melihat hasil }\end{array}$ & $\begin{array}{l}\text { perhitungan nilai cronboch alph } \alpha(\alpha) \text {. } \\
\text { dilakukan dengan variabel dikatakan reliabel jika }\end{array}$
\end{tabular}


memberikan nilai cronb $\alpha$ ch alph $\alpha(\alpha)>$ 0,6 yaitu bila dilakukan penelitian ulang dengan waktu dan variabel yang berbeda akan menghasilkan kesimpulan yang sama. Tetapi sebaliknya bila alph $\alpha(\alpha)<$ 0,6 maka dianggap kurang handal, artinya bila variabel-variabel tersebut dilakukan penelitian ulang dengan waktu yang berbeda akan menghasilkan kesimpulan yang berbeda.

Hasil Pengujian reliabilitas dalam tabel di atasmenunjukkan bahwa semua variabel dalam penelitian mempunyai koefisien alph $\alpha(\alpha)$ yang cukup besar yaitu > 0,60 sehingga dapat dikatakan semua konsep pengukur masing-masing variabel dari kuesioner adalah reliabel yang berarti bahwa kuesioner yang digunakan dalam penelitian ini merupakan kuesioner yang handal.

\section{d. Uji Normalitas Kolmogorov}

\section{Smirnov Residual}

Tabel. 4.23 Hasil Uji Normalitas Kolmogorov Smirnov Residual

One-Sample Kolmogorov-Smirnov Test

\begin{tabular}{|ll|r|}
\hline & & Unstandardized Residual \\
\hline Normal Parameters ${ }^{\mathrm{a}, \mathrm{b}}$ & Mean & 99 \\
& Std. Deviation & $0 \mathrm{E}-7$ \\
& Absolute & 1.67484094 \\
Most Extreme Differences & Positive & .093 \\
& Negative & .068 \\
Kolmogorov-Smirnov Z & & -.093 \\
Asymp. Sig. (2-tailed) & & .930 \\
\end{tabular}

a. Test distribution is Normal.

b. Calculated from data.

Sumber: Data hasil SPSS versi 20
Setelah dilakukan uji validitas dan juga uji reliabilitas dan kedua uji tersebut dinyatakan lulus, maka langkah selanjutnya adalah dilakukan uji normalitas.Uji normalitas adalah uji yang bertujuan untuk mengetahui apakah distribusi data dalam variabel yang digunakan normal atau tidak.Uji normalitas yang digunakan disini adalah uji normalitas Kolmogorov Smirnov Residual karena sampel pada penelitian ini $>50$ yaitu berjumlah 99 responden.Data yang baik dan layak digunakan dalam penelitian adalah data yang memiliki distribusi normal. Kriteria yang akan dituju dalam uji ini yaitu jika nilai signifikansi $>0,05$ maka data berdistribusi normal dan sebaliknya jika nilai signifikan $<0,05$ maka data berdistrusi tidak normal. Adapun ouput dari uji normalitas ini sebagai berikut: 
Berdasarkan hasil uji Normalitas dalam Kolmogorov Smirnov Residual di atas dapat diketahui bahwa nilai signifikansi sebesar0,353>0,05 sehingga dapat dikatakan bahwa data tersebut berdistribusi normal.

\section{e. Analisis Regresi Sederhana}

Tabel 4.24Uji Regresi Linear Sederhana
Pada penelitian ini teknik analisa data yang digunakan adalah regresi sederhana.Teknik analisa ini digunakan untuk mengetahui besarnya pengaruh antara relationship marketing (x) terhadap peningkatan pengunung (y) pada Hotel Harper Perintis Makassar. Dengan mengunakan SPSS maka didapat hasil Regresi sebagai berikut:

\section{Coefficients $^{\mathrm{a}}$}

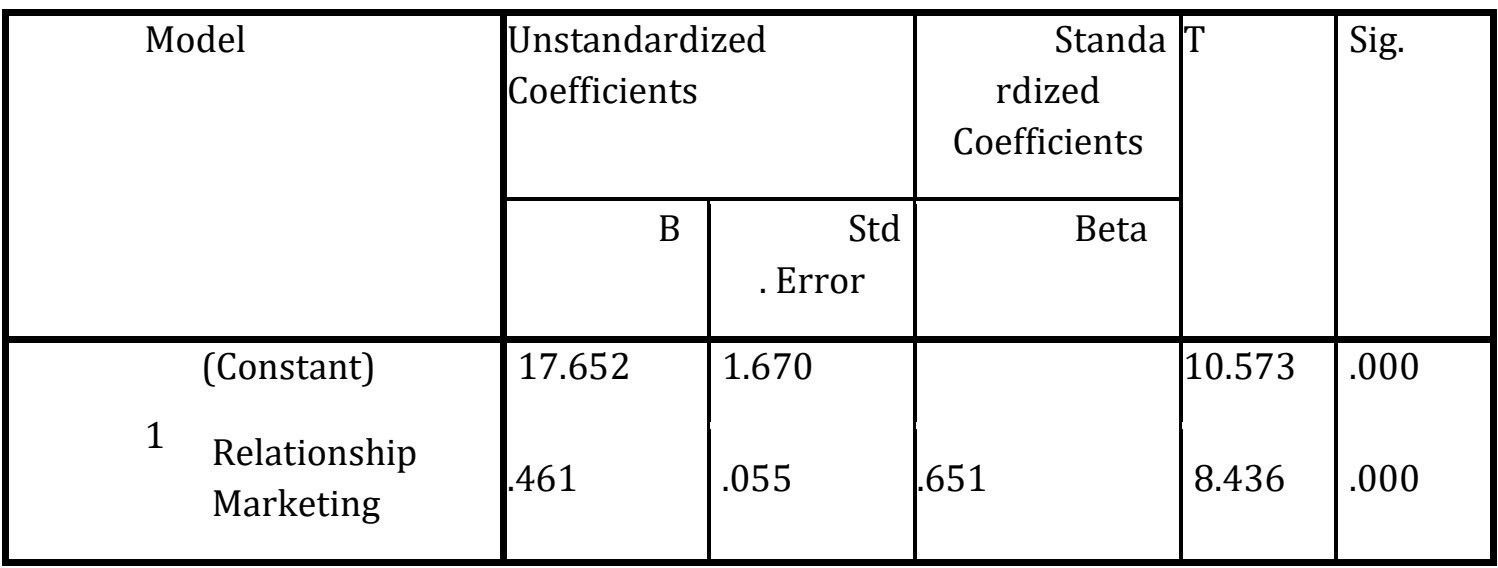

a. Dependent Variable: Peningkatan Pengunjung

Sumber: Data Hasil SPSS versi 20

$\mathrm{Y}=\mathrm{a}+\mathrm{bX}$

$Y=17,652+0,461 X$

$\mathrm{a}=17,652$ (constant)

$\mathrm{b}=0,461$ (Relationship Marketing)

$\mathrm{Y}=$ Peningkatan Pengunung

1. Uji Persial $(\mathrm{t})$

Uji parsial (t) dalam analisis regresi sederhana bertujuan untuk mengetahui apakah variable bebas $\mathrm{X}$ secara persial berpengaruh signifikan terhadap variable Y. Pengambilan keputusan berdasarkan nilai $\mathrm{t}_{\text {hiting }}$ dan $t_{\text {tabel }}$ dan berdasarkan nilai signifikansi.

- $t_{\text {hitung }}>\quad t_{\text {tabel }}=$ Variabel bebas berpengaruh terhadap variable terikat.
- $t_{\text {hitung }}>t_{\text {tabel }}=$ Variabel bebas tidak berpengaruh terhadap variabel terikat.

- Sig $>0,05=$ Variabel bebas tidak berpengaruh signifikan terhadap variabel terikat.

Adapun hasil uji-t secara ringkas dirangkum pada tabel berikut ini: 
Tabel 4.25 Hasil Uji Parsial (Uji t)

\section{Coefficients $^{\mathrm{a}}$}

\begin{tabular}{|c|c|c|c|c|c|}
\hline \multirow[t]{2}{*}{ Model } & \multicolumn{2}{|c|}{ Unstandardized Coefficients } & \multirow{2}{*}{\begin{tabular}{|l}
$\begin{array}{l}\text { Standardized } \\
\text { Coefficients }\end{array}$ \\
Beta
\end{tabular}} & \multirow[t]{2}{*}{$\mathrm{T}$} & \multirow[t]{2}{*}{ Sig. } \\
\hline & B & Std. Error & & & \\
\hline (Constant) & 17.652 & 1.670 & & 10.573 & .000 \\
\hline $\begin{array}{l}\text { Relationship } \\
\text { Marketing }\end{array}$ & .461 & 055 & .651 & 8.436 & .000 \\
\hline
\end{tabular}

a. Dependent Variable: Peningkatan Pengunjung

Sumber: Data Hasil SPSS versi 20

Hasil uji-t dari variabel relationship Marketing memiliki nilai $t_{\text {hitung }}=8,436$ sedangkan $t_{\text {tabel }}$ pada taraf signifikansi $5 \%$ adalah $=1,98472$ Dikarenakan $t_{\text {hitung }}>$ $t_{\text {tabel }}(8,436>1,98472)$. Artinya variabel relationship marketing secara statistik berpengaruh secara siginfikan terhadap peningkatan pengunung.

\section{Uji Simultan (Uji f)}

Dalam penelitian ini uji $f$ pada dasarnya menunjukkan apakah semua variabel bebas yang dimasukkan dalam model mempunyai pengaruh secara simultan terhadap variabel terikat.Dalam penelitian ini penguji hipotesis secara Tabel 4.26 Hasil Uji Simultan (Uji f / ANOVA) simultan dimaksudkan untuk mengukur besarnya pengaruh variabel independent yaitu Relationship Marketing (x) terhadap variabel dependent Peningkatan Pengunjung (y). Hasil uji $\mathrm{f}$ melalui program SPSS versi 20 dilihat pada table berikut:

Ho :Relationship marketing secara bersama-sama tidak meningkatkan pengunjung pada Hotel Harper Perintis Makassar.

Ha :Relationship marketing secara bersama-sama meningkatkan pengunjung pada Hotel Harper Perintis Makassar.

\section{ANOVAa}

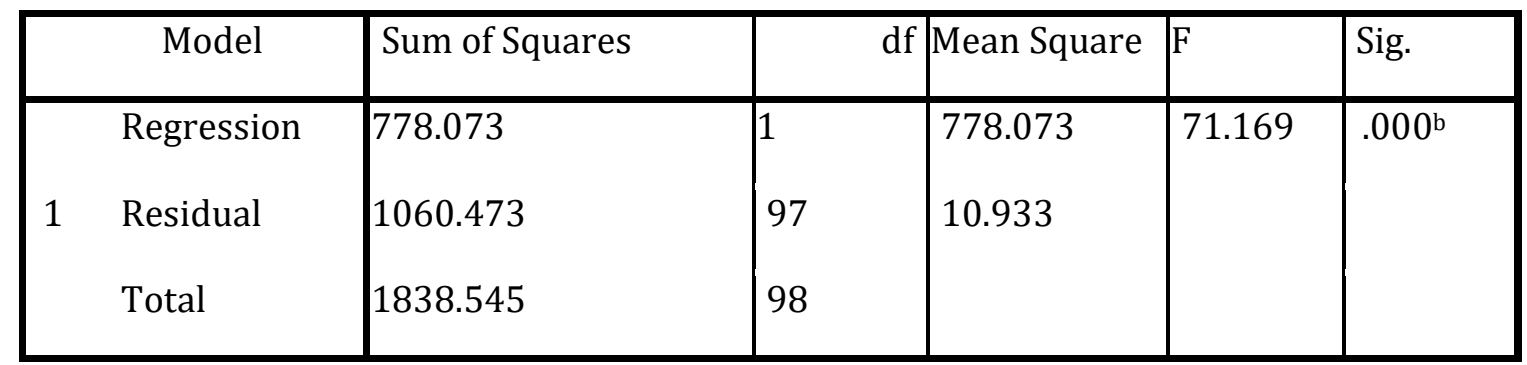

a. Dependent Variable: Peningkatan Pengunjung

b. Predictors: (Constant), Relationship Marketing

Sumber: Hasil Olah SPSS Versi 20 
Berdasarkan hasil pengujian regresi secara simultan di atas, yang ditunjukkan pada table di atas dijelaskan bahwa nilai signifikan sebesar 0.000 maka dapat disimpulkan Ho ditolak. Ha diterima karena dilihat dari nilai positif signifikansinya yaitu P-value $<0.05$ atau $0.000<0.05$. Oleh karena itu dapat disimpulkan bahwa dengan tingkat kepercayaan sebesar 95\%, variabel relationship marketing secara bersamaTabel 4.27 Hasil Uji Koefisien Determinasi sama meningkatkan pengunjung pada Hotel Harper Perintis Makassar.

\section{Uji Koefisien Determinasi}

Setelah memperoleh nilai koefisien b serta persamaan garis regresinya maka untuk mengukur signifikan antara variabel relationship marketing (X) terhadap variabel penigkatan pengunjung $(\mathrm{Y})$ dengan cara menghitung koefisiennya sebagai berikut:

Model Summary

\begin{tabular}{|c|r|r|r|r|}
\hline Model & $\mathrm{R}$ & $\begin{array}{r}\mathrm{R} \\
\text { Square }\end{array}$ & $\begin{array}{r}\text { Adjusted } \\
\text { R Square }\end{array}$ & $\begin{array}{r}\text { Std. Error } \\
\text { of the Estimate }\end{array}$ \\
\hline 1 & .65 & .423 & .417 & 3.30646 \\
\hline
\end{tabular}

a. Predictors: (Constant), Relationship Marketing

Sumber: Data Hasil SPSS versi 20

Berdasarkan tabel diatas diperoleh nilai $\mathrm{R}$ sebesar 0,651 Hal ini menunjukkan bahwa variabel independen yaitu relationship marketing memiliki hubungan (korelasi) yang kuat sebesar $65,1 \%$.

Untuk mengukur derajat kecocokan atau ketepatan antara variabel $\mathrm{X}$ terhadap variabel $\mathrm{Y}$ dapat dilihat dari nilai koefisien determinasi $(\mathrm{R}$ square) yaitu sebesar 0,423 atau dipersenkan menadi 42,3\% yang berarti bahwa variabel independen relationship marketing (X) dalam penelitian ini mempengaruhi variabel dependen peningkatan pengunung $(\mathrm{Y})$ dengan nilai sebesar 42,3\% yang di ambil dari tabel SPSS model summary yaitu R square, dan sedangkan selebihnya sebesar $57,7 \%$ dipengaruhi oleh variabel lain yang tidak terdapat dalam penelitian ini.

\subsection{Pembahasan}

Pembahasan dalam penelitian ini menjelaskan mengenai pengaruh relationship marketing terhadap peningkatan pengunjung pada Hotel Harper Perintis Makassar. Hasil menunjukkan bahwa semua variabel relationship marketing berpengaruh terhadap peningkatan pengunjung. Lebih jelasnya akan dibahas sebagai berikut: Relationship marketing terhadap peningkatan pengunjung

Menurut Saputra dan Ariningsih (2014) Relationship marketing merupakan sebuah konsep strategi pemasaran yang berupaya menjalin hubungan jangka panjang dengan para pelanggan, yaitu mempertahankan hubungan yang kokoh dan saling menguntungkan antara penyedia jasa dan pelanggan yang dapat membangun transaksi ulangan dan menciptakan loyalitas pelanggan. Menurut 
International Union of Official Travel Organization (IUOTO),peningkatan berarti kemajuan, secara umum peningkatan merupakan upaya untuk menambah derajat, tingkat, dan kualitas maupun kuantitas. Sedangkan pengunjung yaitu setiap orang yang datang ke suatu negara atau tempat tinggal lain dan biasanya dengan maksud apapun kecuali untuk melakukan pekerjaan yang menerima upah.

Berdasarkan hasil analisis yang telah dirinci pada bagian terdahulu diperoleh hasil bahwa secara statistic hasil uji $t_{\text {hitung }}$ sebesar $=8,436$ dan ternyata nilai signifikan $=0,000$ berada dibawah 0,05 maka Ho ditolak hal ini didukung pula oleh hasil uji $\mathrm{F}$ (Anova) ternyata diperoleh sebesar 0,000. Dikarenakan probabilitas lebih kecil dari pada 0,05 maka Ho di tolak artiya benarbenar terdapat pengaruh yang signifikan antara relationship marketing terhadap peningkatan pengunjung. Hal ini sejalan dengan penelitian sebelumnya yang dilakukan Gina Herdian (2013), dalam penelitian tersebut disimpulkan bahwa relationship marketing secara simultan dan parsial mempunyai pengaruh yang positif terhadap loyalitas nasabah Bank BTPN KCP Sepanjang.

Berdasarkan hasil penelitian relationship marketing terhadap peningkatan pengunjung pada Hotel Harper Perintis Makassar. Dari hasil uji-t dengan variabel relationship marketing memiliki nilai $t_{\text {hitung }}=8,436$ sedangkan $t_{\text {tabel }}$ pada taraf signifikansi $5 \%$ adalah $=$ 1,98472 Dikarenakan $t_{\text {hitung }}>t_{\text {tabel }}(8,436$ $>1$,98472). Artinya variabel relationship marketing secara statistik berpengaruh secara positif dan signifikan terhadap peningkatan pengunjung.Maka relationship marketing pada perusahaan memiliki peran sangat penting dalam memaujukan peningkatan pengunjung.

\section{PENUTUP}

\subsection{Simpulan}

Berdasarkan pengolahan dan hasil dari uji-uji data dalam penelitian ini, maka dapat disimpulkan bahwa:

1. Berdasarkan hasil uji validitas dapat dinyatakan bahwa relationship marketing berpengaruh terhadap peningkatan pengunjung, berdasarkan hasil analisis menunjukkan bahwa $r_{\text {hitung }}>r_{\text {tabel }} \mathrm{n}$ $2=99-2=97$ (0.1975) pada taraf signifikan 5\%, artinya tiap item pernyataan/indikator variabel relationship marketing dengan peningkatan pengunjung berkolerasi dengan skor totalnya serta data yang dikumpulkan dinyatakan valid dan siap untuk dianalisis, serta hasil uji reliabilitas memperoleh nilai koefesien reliabilitas yang lebih besar dari 0,6. Sesuai dengan pernyataan, dinyatakan reliabel (handal) jika nilai cronbach's alpha lebih besar dari 0,6. Jadi, dapat dinyatakan bahwa seluruh pernyataan dalam kuesioner adalah reliabel (dapat diandalkan).

2. Berdasarkan hasil uji normalitas Kormogorov Smirnov residual menggunakan SPSS versi 20 didapatkan bahwa Understandarized Residual dengan nilai $0.353>0.05$ maka nilai residual berdistribusi normal artinya dapat dilakukan uji selanjutnya yaitu uji regresi linear karena syarat melakukan uji regresi linear yaitu apabila data yang dikumpulkan valid, reliabel, dan berdistribusi normal.

3. Berdasarkan hasil penelitian mengenai pengaruh relationship marketing terhadap peningkatan 
pengunjung pada Hotel Harper Perintis Makassar dapat dibuat kesimpulan bahwa relationship marketing berpengaruh positif dan signifikan terhadap peningkatan pengunjung pada Hotel Harper Perntis Makassar. Hal tersebut dibuktikan dari hasil uji regresi sederhana dengan nilai $t_{\text {hitung }}>t_{\text {tabel }}$ yaitu (8.436>1.98472) dan nilai signifikan sebesar $0.00<0.05$ maka dapat disimpulkan bahwa $H_{0}$ ditolak dan $H_{a}$ diterima yang berarti variabel relationship marketing berpengaruh terhadap peningkatan pengunjung secara signifikan.

\subsection{Saran}

Berdasarkan hasil analisis serta hasil kesimpulan yang dilakukan oleh peneliti maka saran yang diberikan sebagai bahan informasi bagi Hotel Harper Perintis Makassar antara lain :

1. Sehubungan dengan variabel relationship marketing yang terdiri dari trust (kepercayaan), commitment (komitmen), communication (komunikasi), dan conflict handling (penanganan konflik) yang sangat mempengaruhi peningkatan pengunjung, agar mampu mempertahankannya agar bias bersaing dengan hotel-hotel lainnya yang mulai berkembang.

2. Hotel hendaknya mempertahankan kegiatan promosi penjualan agar target peningkatan jumlah pengunjung dapat tercapai untuk membuat pengunjung tidak beralih kepada hotel sejenis.

3. Perlu dilakukan evaluasi yang berkala sehingga dapat diketahui kendalakendala yang dihadapi dalam masalah kualitas pelayanan terhadap peningkatan pengunjung.

\section{DAFTAR PUSTAKA}

Abdurrahaman, N.H. 2015. Manajemen Strategi Pemasaran. Cv. Bandung: Pustaka Setia.

Arta Jiwa, Nyoman I Dewa. 2018. Relationship Marketing, Power, dan Loyalitas pada Hubungan Bisnis antara Pemasok dan Peritel. Jurnal Mitra Manajemen (JMM Online). Vol. 2, No. 3, 146-159.

Ball at al. 2014.Halves, Pieces and Twoths: Constructing and Using Representational Context in Teaching Fractions. East Lansing, Mich: National Center for Research on Teacher Education.

El Citra, Gempita Santi Swari. 2015. Pengaruh Customers Relationship Marketing dan Customer Value terhadap Customer Loyalty. Jurnal Ilmiah. Vol. 2, No. 4.

Herdian, Gina. 2013. Pengaruh Relationship Marketing terhadap Loyalitas Pelanggan pada Nasabah Bank BTPN KCP Sepanjang. Jurnal Bisnis dan Manajemen (BISMA).Vol. 6, No. 1.

http://www.bisnis.com/hotel/2015/05/ perkembangan-hotel-

bisnis.html.Diakses 28 Januari 2019.

html://id.shroong.com/businessmanagement/management/218642 8-pengertian-atau-definisihotel.Diakses 24 Januari 2019. http://www.bisnis.com/hotel-dimakassar-menjamur-phriharapkan-tak-ada-lagi-izinbaru. Diakses 21 Januari 2019.

Hurriyati, Ratih. 2015. Bauran Pemasaran dan Loyalitas Konsumen. Bandung: Alfabetha.

Internasional Union of Official Travel Organization (IUOTO) tentang Peningkatan Pariwisata. 
Kotlerdan Amstrong.2014. Principle of Marketing. 15th Edition. Pearson, New Jersey.

Kotler dan Keller. 2013. Marketing Management, $14^{\text {th }}$ Edition. New Jersey. Prentice Hall International, Inc.

Oktaviani, Femi. 2015. Relationship Marketing dalam Mengembangkan Objek Wisata "Studi Kasus pada Paguyuban Alam PakidulanSukabumi/ PAPSI Geopark Ciletuh Sukabumi". Jurnal Sketsa. Vol. 11, No. 1.

Peraturan Mentri Perhubungan No.KM 37 PW.340/MPPT-86 Tentang Peraturan Usaha dan Pengelolaan Hotel.

Peraturan Mentri Perhubungan (SK. MenHub. No. PM 10/PW 391/PHB77) Tentang Pelayanan Penginapan Makan dan Minum.

Robinette, Scot. 2013. Emotion Marketing. New York: Mc. Graw Hill Book Company.

R.S. Darmardjati. 2015. Istilah-Istilah Pariwisata. Bandung: Alfabeta.

Sangaji, E. M, and Sopiah. 2013. Perilaku Konsumen. Yogyakarta: Andi Ofset.

Sivesan. 2013. Impact of Relationship Marketing and Customer Loyaltyon Banking Sectors, Journals of South Academic Research. Volume 2, Issue 3, pp. 179-191

Sonkova, Tereza, dan Grabowska, Monika. 2015. Customer engagement: transactional vs relationship marketing". Journal of International Studies Volume 8, No. 1:196-207.

Sulistiono. 2013. Manajemen Penyelenggaraan Hotel: Manajemen Hotel. Bandung: Alfabeta.

Sumarsono. 2014. Sosiolinguistik. Yogyakarta: SABDA.
Sugiarto. 2013. Struktur Modal, Struktur Kepemilikan Perusahaan, Permasalahan Keagenan, dan Informasi Asimetri. Yogyakarta: Graha Ilmu.

Sugiyono. 2015. Metode Penelitian Dan Pengembangan. Bandung: Alfabeta.

Tauni dan Khan. 2014. Impact of Brand Related Attributes on Purhase Intention of Customers. A Study About the Customers of Punjab, Pakistan. Interdisiplinary Journal of Contemporery Research in Business.

Velnamply dan Sivesan. 2013. Customer Relationship Marketing and Customer Satisfaction: A Study on Mobile Service Providing Compainess In Srilangka, Journal of Business Org.

Wahyuni, Rika. 2017. Pengaruh Relationship Marketing, Kepuasan, dan Brand Image, terhadap Loyalitas Pelanggan Restoran Sederhana Masakan Padang. Jurnal EKOBISTEK. Vol. 6, No. 2. 